\title{
Does Digital Marketing Affect Millennial Purchase Decision in Covid-19 Situation?
}

\author{
Tika.A Koeswandi ${ }^{1, *}$ Lili.Adi Wibowo ${ }^{2,}$ Mira. Nurfitriya ${ }^{3}$ \\ ${ }^{1}$ Universitas Pendidikan Indonesia \\ ${ }^{2}$ Universitas Pendidikan Indonesia \\ ${ }^{3}$ Universitas Pendidikan Indonesia \\ *Corresponding author. Email: tikakoeswandi@upi.edu
}

\begin{abstract}
This study aims to figure out how digital marketing affects Indonesia's millennial purchase decision during the Covid19 era. This study is a descriptive-quantitative that involved 100 millennial costumers in West Java, Indonesia, as a sample who had social media and purchased at least once in the fashion sector of Small Medium Enterprises (SMEs). The data were collected through a survey questionnaire and interviewed through google meetings. The data were analyzed through simple regression using SPSS 23.0. The results of this study show t-count 3.211> table 1.984 with sig. equal to 0,000 , which means that the variable of digital marketing has a positive and partially gives significant effect to the millennial purchase decision. The R Square number of $30.7 \%$ shows the influence of the free variable (digital marketing) on the dependent variable (millennial purchase decision). This implies that the more intense digital marketing is applied in the Covid-19 situation, the more influence receives by millennials to make a purchase decision.
\end{abstract}

Keywords: digital marketing, millennia, purchase decision, covid-19.

\section{INTRODUCTION}

At the beginning of 2020, Indonesia has experienced a coronavirus outbreak, leading to a new movement in the business sector. Corona Virus itself, according to [1] is a group of viruses that can cause disease in animals or humans which cause respiratory infections in humans ranging from cold coughs to more serious ones such as Middle East Respiratory Syndrome (MERS) and Severe Acute Respiratory Syndrome (SARS). This new type of Coronavirus has been found to cause COVID-19. The Covid-19 was first found in Wuhan, China, at the end of 2019 and started to spread worldwide in less than 3 months and infected Indonesia's first case in February 2020.

The government started to take serious action to minimize the virus's movement by declaring a policy to close the school, business, and tourism. Many sectors got affected, and many people got minimized to do activities. The new terms WFH (Work From Home), MFH (Meeting From Home), and SFH (Study From
Home) are becoming more familiar since many industries apply new protocols in dealing with employee activity. To maintain sustainability, many Small Medium Entreprises (SMEs) in Fashion Industry applied digital marketing strategies.

Digital marketing is sometimes confused with online marketing. According to reference [2]"Digital Marketing was conceptualized as a projection of conventional marketing, its tools, and strategies, on Internet." Three types of media must be used in a coordinated fashion to maximize a digital marketing strategy's efficiency, namely: Owned Media, Earned Media, and Paid Media. The benefits of using the form of digital marketing are helping the company in increasing the sales volume, gaining brand awareness, and influencing the customer purchase-buying decision [3-5].

These beneficial aspects of having digital marketing as a strategy do not necessarily mean fit to any customer. Millennial as the biggest number statistic of a 
productive citizen in Indonesia has been one of many SMEs' concern. The fashion industry, as an example, will hire an endorsement from one of the famous artists or influencers to build trust from the customer [6]. This is because Millennial customers have their preference in doing online purchasing.

Thus, research regarding how digital marketing affects the Millennial buying decision in Covid-19 is needed to be conducted in the hope there will enrich the knowledge of digital marketing \& millennial customer and also give a model of the effect of digital marketing for SMEs in Indonesia.

The previous studies regarding digital marketing and purchase decision have been conducted [7-10].

\subsection{Digital marketing}

Digital marketing is sometimes confused with online marketing. According to Piñeiro [2] , "Digital Marketing was conceptualized as a projection of conventional marketing, its tools, and strategies, on Internet." There are three types of media that must be used in a coordinated fashion to maximize a digi-tal marketing strategy's efficiency, namely: Owned Media, Earned Media, and Paid Media.

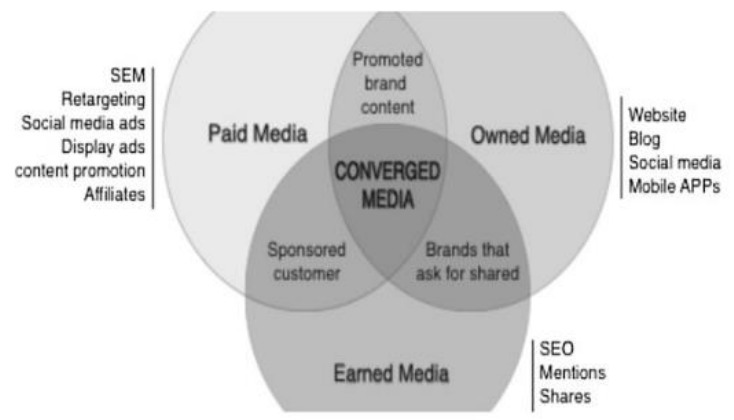

Figure 1. Convergence Media in Digital Marketing

- Owned Media: Owned media is conceptualized as digital media owned by the companies where companies can con-trol the content in a limited space of time in the channel such as website, blog, social network profile $\mathrm{s}$ and mobile apps [2].

- $\quad$ Earned Media: It is conceptualized as a media that is controlled by the external of the company to help to promote activity for free. The form of earned media can be mentions, shares, reposts, reviews, recommendations, product reviews on specialized Webs or assessments on online shops or specific social platforms (e.g., Ciao! or TripAdvisor) and Search Engine Optimation (SEO) [2].
- Paid Media:Paid media is a media of digital marketing that gets the companies to pay for space and content. The form of paid media can be paid to promote in Insta-gram, Pay Per Click, or promoted tweet [2]

The benefits of using the form of digital market-ing are helping the company in increasing the sales volume, gaining brand awareness, and influencing the customer purchase-buying decision [3-5].

\subsection{Millennial's Purchase Decision}

The purchase decision is the fourth stage in Kotler's Five Stage Model of Consumer Behavior. There are some differences between traditional and online purchase decisions, one of them, according to Moustakas [7], is "a risky alternative due to the absence of personal contact, the inability to have phys-ical product evaluation, and in some cases, the lack of secure transactions." But for Millennials, this risky alternative may not probably a big deal

At this study, millennial is a group of citizens born in late 1980 until the beginning of 2000. Unlike Gen X, they are not a 'digital native.' They like to go online, but they also prefer to walk down to the traditional market. Millennials have a unique digital input, and they prefer to see the review, digital coupon, recommendation, rating, and IoT integrating before buying the product [11].

There have been many studies regarding how digital marketing can affect millennial purchase de-cisions in the last five years. However, the studies were found in a non-virus outbreak situation where the results found that digital marketing can influence how millennials decide to purchase online in pan-demic situation $[12,10,9]$

\section{METHODS}

This research is descriptive quantitative research with included 100 millennials who were born around 1988-1994. They consisted of 55 girls and 45 boys who live in West Java, Indonesia, and are students in University, fresh graduates, and workers who have experienced once in buying fashion online of Indonesian SMEs during covid-19. The sampling tech-nique chosen was incidental sampling, a sampling technique based on coincidence, such as anyone who met the criteria. Questionnaire through google form and interview through google meeting were con-ducted to collect data. The data were then analyzed by using a simple regression technique with SPSS.

\section{RESULTS AND DISCUSSION}

The categories of respondents in this study are concluded into a table, as follows table 1. 
Table 1. Respondents' category

\begin{tabular}{|c|l|l|}
\hline \multicolumn{2}{|c|}{ Category } & \multicolumn{1}{c|}{ Percentage } \\
\hline Gender & \multicolumn{1}{|c|}{ Female } & $45 \%$ \\
\hline Age & 29 & $55 \%$ \\
\hline & 28 & $9 \%$ \\
\hline & 27 & $21 \%$ \\
\hline & 26 & $13 \%$ \\
\hline & 25 & $10 \%$ \\
\hline Occupation & Worker & $36 \%$ \\
\hline & Fresh graduate & $41 \%$ \\
\hline & Unemployment & $22 \%$ \\
\hline Status & Single & $37 \%$ \\
\hline & Married & $51 \%$ \\
\hline & others & $47 \%$ \\
\hline Salary/month & $>5$ million IDR & $37 \%$ \\
\hline & $3-5$ million IDR & $31 \%$ \\
\hline & $<3$ million IDR & $32 \%$ \\
\hline Source: Author & &
\end{tabular}

Meanwhile, the result of the data analysis is shown in the explanation below Table 2.

Table 2. Model Summary

\begin{tabular}{|c|c|c|c|c|}
\hline Model & R & R Square & $\begin{array}{c}\text { Adjusted R } \\
\text { Square }\end{array}$ & $\begin{array}{c}\text { Std. Error of the } \\
\text { Estimate }\end{array}$ \\
\hline 1 & $.309^{\mathrm{a}}$ & .096 & .087 & 3.55640 \\
\hline
\end{tabular}

Predictors: (constant), Digital Marketing

Table 2 shows the magnitude of the correlation or relationship (R) value equal to 0.309 . From the out-put obtained, a coefficient of determination ( $\mathrm{R}$ square) of 0.096 implies that the effect of the variable digital marketing on millennial buying decisions is $9.6 \%$.

The result of anova is shown in the explanation below table 3 .

Table 3. ANOVA

\begin{tabular}{|c|l|l|l|l|l|}
\hline Model & \multicolumn{1}{|c|}{$\begin{array}{c}\text { Sum of } \\
\text { Squares }\end{array}$} & \multicolumn{1}{|c|}{ df } & $\begin{array}{c}\text { Mean } \\
\text { Square }\end{array}$ & F & Sig. \\
\hline Regression & 131.247 & 1 & 131.247 & 10.377 & $002^{\mathrm{b}}$ \\
\hline Residual & 1239.503 & 98 & 12.648 & & \\
\hline Total & 1370.750 & 99 & & & \\
\hline
\end{tabular}

Dependent Variable: Millenial Purchase Decision

Predictors: (Constant), Digital Marketing

Table 3 shows the calculated $\mathrm{F}$ value $=12,648$ with a significance level of $0,000<0.05$. The regression model can be used to predict participation variables or, in other words, digital marketing affects the millennial's buying decision.

The result of coefficients is shown in the explanation below table 4 .

Table 4. Coeficients

\begin{tabular}{|c|c|c|c|c|c|}
\hline \multirow{2}{*}{ Model } & \multicolumn{2}{|c|}{$\begin{array}{c}\text { Unstandardized } \\
\text { Coefficients }\end{array}$} & $\begin{array}{c}\text { Standardized } \\
\text { Coefficients }\end{array}$ & \multirow{2}{*}{ Sig. } \\
\cline { 2 - 4 } & $\boldsymbol{B}$ & Std. Error & Beta & & \\
\hline (Constant) & 14.046 & 3.620 & & 3.880 .000 \\
\hline
\end{tabular}

\begin{tabular}{|l|l|l|l|l|l|}
\hline $\begin{array}{l}\text { Digital } \\
\text { Marketing }\end{array}$ & .307 & .095 & .309 & 3.221 .002 \\
\hline
\end{tabular}

Dependent Variable: Millennial Purchase Decision

Table 4 shows the constant value (a) of 14.056 while the value of digital marketing ( $\mathrm{b} /$ regression coefficient) of 0.307. It can be explained that the constant of 13.509 implies that the consistent value of the millennial purchase decision variable is equal to 14,056 . Meanwhile, the digital marketing coeffi-cient regression that is 0.307 tells for each addition of $1 \%$ digital marketing value, the value of millennial purchase decision will increase by 0.307 . The regression coefficient is considered positive, so it can be said that the direction of the influence of digital marketing on the millennial purchase decision is also positive.

From table 4 , it can be found that the significance value is $0,000<0.05$. Thus, it can be concluded that digital marketing affects the millennial purchase decision. From table 3, it can also be seen that the T-value is 3,221 > T-table 1,984 . So, it can be con-cluded that the digital marketing variable affects millennial purchase decisions.

So that, the model of the influence of digital marketing through millennial purchase decision can be drawn by Fig. 2 .

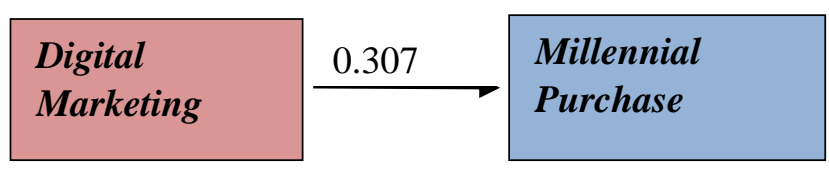

Figure 2. Model of the influence of digital marketing through the millennial purchase decision

This study shows that digital marketing can affect the millennial's decision-making process in purchasing fashion products online in the Covid-19 Situation. This is because digital marketing, through visu-al, audio, and text, helps promote, provide information, educate and trigger the millennial's motivation to buy. Even though most millennials stay at home in the Pandemic situation to do their activities, they still consider having a good fashion in supporting their activities. This can be why millennials tend to have a well-dressed performance on any occasion, both pre and during the pandemic.

This study has completed the previous study both in prior and during Pandemic [3-5] that digital marketing is helping the company in increasing and influencing the customer purchase-buying decision. This applies the most to the Indonesian-single-workerwith more than 5 million IDR salary/month customers. This millennial still pays attention to fashion and clothes during Covid-19 since Work From Home (WFH) \& Meeting From Home (MFH) is held online. 


\section{CONCLUSION}

This study concludes that even though the Government has declared to stop the offline business and minimize the business movement in Indonesia due to Covid-19, digital marketing can help the fashion Small Medium Enterprises (SMEs) keep maintaining the business. The most interesting point is that both in the non-virus outbreak, as in line with the studies from Qazzafi and Tandon [10], and during virus outbreak, digital marketing influences the millennial customer in helping the purchase decision.

The study implies that the more intense digital marketing is applied in the Covid-19 situation, the more influence receives by millennials to make a purchase decision.

For further research, this study recommends finding out how digital marketing affects the millennial's purchase decision after Covids-19 as an input for the Indonesian government to rebuild the economic situation.

\section{ACKNOWLEDGMENT}

This paper is supported and granted by Universi-tas Pendidikan Indonesia in Batch II UPI World Class University Program 2020. The authors would also like to give a special thanks to all the participants and the committee of The 5th Global Confer-ence on Business, Management and Entrepreneur-ship 2020

\section{REFERENCES}

[1] WHO, "Rolling updates on coronavirus disease (COVID-19)," 2020.

[2] T. Piñeiro-Otero and X. Martínez-Rolán, Understanding Digital Marketing-Basics and Actions, no. September. 2016.

[13] . Rev. (The Job Rev., vol. 3, no. 1, pp. 11-14, 2020.
[3] S. Kingsnorth, Digital Marketing Strategy: An integrated approach to online marketing. 2016.

[4] A. Hendrawan, H. Sucahyowati, K. Cahyandi, Indriyani, and A. Rayendra, "Pengaruh Marketing Digital Terhadap Kinerja Penjualan Produk UMKM Asti Gauri di Kecamatan Bantasari Cilacap," J. Adm. dan Kesekretarisan, vol. 4, no. 1, pp. 53-60, 2019.

[5] A. I, Nabila Rufaida; Suyanto, "Analysis the Impact of Digital Marketing of the Brand Awareness," eProceeding Manag., vol. 6, no. 2, pp. 2091-2097, 2019.

[6] A. Ricky and D. S. Pratiwi, "Effects Of Celebrity Endorsement On Customer Trust And Loyalty: Case Study On Pilgrims In Aceh," vol. 40, no. Icame, pp. 281-298, 2017.

[7] E. Moustakas, "the Impact of Social Networking on Consumer Behaviour," Middlesec Univ. Dubai, vol. 4, no. 7, pp. 37-54, 2012.

[8] T. A. Koeswandi and E. A. Primaskara, "The Effect of Servicescape on e-Trust (Online Survey on Shoppee Mobile Application Users in Bandung)," Adv. Business, Manag. Entrep. Proc. 4th Glob. Conf. Bus. Manag. Entrep. (GC-BME 4) 8 August 2019, Bandung, Indones., pp. 463-466, 2020.

[9] N. Tandon and S. Kaur, "Impact of Digital Market on Consumer Buying Behaviour," Natl. Conf. People, no. May, p. 5, 2018.

[10] S. Qazzafi, "Consumer Buying Decision Process Toward Products," no. September, 2019.

[11] D. Newman, S. Kramer, and O. Blanchard, "Marketing to Millenials," pp. 1-24, 2020.

[12] T. A. Koeswandi, T. Fauziyah A, and M. Nurfitriya, "Digital Marketing Design to Increase Tourism and Maintain City Image.,” Int. J. Bus 